Relations industrielles

Industrial Relations

\title{
A Note on the Incomes of Lawyers
}

\section{Lars Osberg}

Volume 40, numéro 4, 1985

URI : https://id.erudit.org/iderudit/051383ar

DOI : https://doi.org/10.7202/051383ar

Aller au sommaire du numéro

\section{Éditeur(s)}

Département des relations industrielles de l'Université Laval

\section{ISSN}

0034-379X (imprimé)

1703-8138 (numérique)

Découvrir la revue

\section{Citer cet article}

Osberg, L. (1985). A Note on the Incomes of Lawyers. Relations industrielles /

Industrial Relations, 40(4), 865-879. https://doi.org/10.7202/051383ar

Tous droits réservés (C) Département des relations industrielles de l'Université Laval, 1985
Ce document est protégé par la loi sur le droit d'auteur. L’utilisation des services d'Érudit (y compris la reproduction) est assujettie à sa politique d'utilisation que vous pouvez consulter en ligne.

https://apropos.erudit.org/fr/usagers/politique-dutilisation/ 


\section{DISCUSSIONS}

\section{A Note on the Incomes of Lawyers}

\section{Lars Osberg}

In 1961, Canadian law schools graduated 697 new lawyers but by 1980 their annual output had increased to 3017. The number of self-employed lawyers more than doubled and, as most economists would predict, average legal incomes have fallen in recent years (by some $15.6 \%$, in real terms, between 1971 and 1980$)^{1}$. The legal profession has, as a consequence, become rather concerned about 'oversupply'.

David Stager (1983) has argued against this idea on the basis that the high income elasticity of demand for legal services implies a 'warranted growth rate' for the number of lawyers, which exceeds likely future supply. This argument depends, however, on estimates by Pashigian (1977) of the relationship between the equilibrium number of lawyers in the U.S. and the growth rate of GNP. The present paper argues that there is good reason to believe that the market structure for legal services is not the same in the U.S. and in Canada and it presents estimates, using Canadian data, of the determinants of average legal earnings in the Atlantic provinces and the implications of two scenarios for the future supply of legal services.

Since the supply of legal graduates has increased so dramatically in recent years, our forecast is that the 'service ratio' (population per practicing lawyer) will continue to decline steeply in coming decades. Since legal earnings are strongly related to the service ratio, we predict continued declines in incomes for members of the legal profession. These declining earnings are N.S.

- OSBERG, L., Professor, Department of Economics, Dalhousie University, Halifax,

** The Research on which this paper is based was financed by a grant from Dalhousie University. Credit must go to Kevin Reilly for his excellent work on this project, but responsibility for any errors rests with the author. The comments of an anonymous referee have noticeably improved the presentation.

1 In current nominal terms, the average income of self-employed Canadian lawyers and notaries was $\$ 27862$ in 1971 and $\$ 49481$ in 1980. (Taxation Statistics, Revenue Canada). But in 1980 dollars, the 1971 earnings of lawyers were equivalent to $\$ 58695$. 
likely to affect the average future 'quality' of entering classes of law students, but it may be that such a change is socially desirable. Declines in the private benefits of legal education cannot necessarily be identified with declines in the social benefits of legal education. Social policy, i.e. the decision to maintain, restrict or expand the size of the country's law schools, should consider the positive and negative externalities generated by legal activity, as well as private returns to members of the legal profession.

\section{MARKET STRUCTURE}

Unlike medicine, dentistry, architecture, engineering or even economics, the practice of law is highly specific to a particular jurisdiction. Differing legal institutions afford differing opportunities for the exercise of legal skills (e.g., in the need for specific contractual language or in the frequency of court appearances, constitutional challenges to legislation, or appeals) and jurisdictions differ widely in the role played by such alternatives to the court system as conflict arbitration or small claims. The demand for legal services is thus subject to different institutional influences in different jurisdictions - e.g., historically there have been far fewer challenges in Canada to the "constitutionality» of laws than in the U.S., although this difference may diminish with our new constitution.

In the U.S., the existence of a large number of law schools with minimal entrance requirements implies that individuals can always find some way of entering the legal profession. Freeman (1975) has argued that the supply side of the American legal market is highly responsive, with 'cobweb' type fluctuations of three to four years duration. Pashigian (1977) argues that supply responses by law schools are imperfect and that the market has swings of much longer duration. However, his data (1977:78) does indicate the diminishing role played by selective law schools in U.S. legal education - some $90 \%$ of the increase in U.S. law school enrolment over the period 1958 to 1973 came from lower quality public and private institutions.

By contrast, all Canadian law schools have been in an economic situation which allows them to be selective. The major factor determining the flow of new graduates onto the legal market has been the number of seats available in law schools. There has historically been a long queue of potential law students. Over the period 1961 to 1980, the number of new graduates in law in Canada increased from 697 to 3017 , but this rapid increase came about as the result of provincial government decisions on university funding, which were very imperfectly linked to labour market developments. Discrete decisions on the establishment and/or expansion of 
law schools has produced a 'stepped' patterns of law school graduations, with particularly large increases in the early 1970 's. In many respects, the supply of new graduates has been more an exogenous variable than an endogenous variable in the market for legal services in Canada.

One would expect differences on both the supply and demand sides of the legal market to produce appreciable differences in observed outcomes between Canada and the U.S. Pashigian's data (1977:54) indicates that the difference in 'lawyer-intensiveness' of the U.S. and Canadian societies is large, stable and very long-standing. Over the period 1920 to 1970, Canada had an average service ratio of 1300 persons per lawyer while the U.S. had an average of 793. Both countries have had declining service ratios in recent decades (to 1219 per lawyer in Canada in 1971 versus 730 in the U.S.) but the ratio between the two remains remarkably constant.

In addition, bar associations appear to have retained a tighter grip on the profession in Canada than in the U.S. - as witness the greater restraints on professional advertising in Canada. The result is a market that diverges sharply from the 'perfectly competitive' model. Table 1 presents some data from Altman/Weil (1982) to illustrate the dispersion in charges which one observes, even for highly standardized legal services, in Canada ${ }^{2}$.

Variations in fees for standard transactions (such as a house sale) would, one presumes, be less if open advertising were permitted. However, even in this case, and certainly in the case of legal advice on more complex issues, one would expect price dispersion to be a permanent feature of the market for legal services. Professional services, rendered on a long-term basis, create personal relationships. Even in short-term professional relationships, the 'bedside manner' and informal reputation of lawyers is a large part of the degree of confidence which they inspire. Hence, each legal practitioner offers a slightly different commodity for sale, and it follows that the demand curve for professional services faced by each individual practitioner will differ. As a consequence, it seems most appropriate to model the market for legal services as one of 'monopolistic competition'.

In a model of monopolistic competition each individual supplier faces a downward sloping demand curve, which shifts in response to institutional changes, changes in consumer incomes and increases in the number of competitive suppliers. Individual suppliers set their price so as to maximize profit, subject to these demand shifts, and equate the marginal revenue from increased sales with the marginal cost of production - in this case the variable cost of servicing an additional client (ignoring the fixed costs of a

2 There is nothing 'unique' about realt estate transactions - the ALTMAN/WEIL; survey presents similar data on 13 other 'standard' services. 
law practice or the sunk costs of acquiring a legal education). A model of «monopolistic competition $)^{3}$ implies that variations in average legal incomes can be explained by institutional changes, trends in personal incomes and changes in the 'service ratio' (i.e., the population/lawyer ratio), which determine the earnings of self-employed lawyers.

\section{TABLE 1}

Common Fee Charged in 1982 for Representation of Purchaser of a Residence- $\$ 50,000^{\star}$ by Region

Number of Firms Reporting Average Fee of

$\begin{array}{lrrrrrrrr}\text { Region } & <\$ 200 & \$ 200- & \$ 300- & \$ 400- & \$ 500- & >\$ 599 & \begin{array}{c}\text { Average } \\ \text { Fee }\end{array} & \begin{array}{c}\text { Number } \\ \text { Reporting }\end{array} \\ & & 299 & 399 & 499 & 599 & & 3302 & 218 \\ \text { West } & 19 & 77 & 93 & 25 & 3 & 1 & \$ 302 & 477 \\ \text { Ontario } & 0 & 13 & 141 & 131 & 160 & 32 & 433 & 9 \\ \text { Québec } & 4 & 0 & 0 & 3 & 2 & 2 & 300 & 9 \\ \text { Atlantic } & 0 & 0 & 3 & 14 & 25 & 28 & 559 & 70 \\ \text { Total } & 23 & 90 & 237 & 173 & 190 & 61 & \$ 406 & 774\end{array}$

* Representation of the purchaser of a residence, including attendance at the closing when the sales price is $\$ 50,000$.

\section{TABLE 2}

\section{Common Fee Charged in 1982 for Representation of} Purchaser of a Residence-\$100,000* by Region

Number of Firms Reporting Average Fee of

$\begin{array}{lrrrrrrrrr}\text { Region } & <\$ 300 & \$ 300- & \$ 400- & \$ 500- & \$ 700- & \$ 800 & >\$ 999 \text { Average } & \text { Number } \\ & & 399 & 499 & 699 & 799 & 999 & & \text { Fee } & \text { Reporting } \\ \text { West } & 9 & 62 & 76 & 65 & 3 & 1 & 1 & \$ 422 & 217 \\ \text { Ontario } & 1 & 34 & 65 & 116 & 135 & 71 & 56 & 687 & 478 \\ \text { Québec } & 3 & 1 & 2 & 1 & 1 & 1 & 0 & 411 & 9 \\ \text { Atlantic } & 13 & 97 & 144 & 187 & 145 & 109 & 76 & \$ 925 & 167 \\ \text { Total } & 13 & 97 & 144 & 187 & 145 & 109 & 76 & \$ 635 & 771\end{array}$

* Representation of the purchaser of a residence, including attendance at the closing when the sales price is $\$ 100,000$.

ALTMAN AND WEIL, Economic Survey of Canadian Law Firms, Altman and Weil Inc., Management Consultants Ardmore Pennsylvania, 1982.

3 A concise basic summary of this model is contained in MANSFIELD, 1982:310 to 328. 


\section{ECONOMETRIC RESULTS}

A model of a market of 'monopolistic competition' subject to exogenous supply shifts and variations in demand leads one to emphasize single equation estimates of the determinants of the average earnings of self-employed legal practitioners. We present first a simple model, (equation 2:1) which is estimated on Canada-wide data for the period 1956 to 1980. However, since the necessity of qualifying for admission to the bar of each province limits the interprovincial migration of lawyers, one would expect the market for legal services to be segmented by province. If one looks at data for individual provinces a slightly more complex statistical estimation procedure is required since one now has pooled cross-section and time series data. The results for the full specification, for pooled cross-section and time series data on the Atlantic provinces for the period 1956 to 1980 are presented in equation 2:2. The relationship of primary interest (between service ratio and average incomes) is virtually identical in alternative specifications using provincial data and it is these estimates in which we have the greatest confidence ${ }^{4}$. However, it is worth noting that although equation 2:2 implies that average professional incomes will fall by roughly 0.54 for each $1 \%$ increase in the number of self-employed lawyers (holding population constant) the Canada wide estimates $(2: 1)$ would imply a larger decline in professional incomes (i.e., 1.26\%).

The simplest specification of the determinants of average total income from legal practice would be to argue that average legal income depends on the service ratio and on the per capita disposable income of the population at large. Per capita incomes can be usefully separated into their long-run trend component (variable TRENDY) and the year to year variation in incomes that stems from the booms and recessions of the business cycle (variable DEVY).

Department of National Revenue taxation statistics give us the average total income of self-employed legal practitioners for the years 1956 to 1980 (variable AVINCLAW). From Statistics Canada we can obtain data on national and provincial populations, per capita disposable income, and, from them, calculate the service ratio (variable SRATIO) and the income variables TRENDY and DEVY.

We can also obtain measures of such potential influences on income from legal practice as the number of housing starts and divorces. The number of new housing starts (in logs, variable HOUSE) might be seen as a

4 Alternative specifications and additional data are available in OSBERG (1983) copies of which are available from the author on request. 
proxy for total activity in the real estate market, and the greater the volume of real estate transactions, the greater, one would expect, would be the legal fees generated by real estate work. Similarly, rising numbers of divorces generate work for lawyers, hence we include as a potential explanatory variable DIVORCE, the natural logarithm of the number of divorces. However, since divorce reform in 1968 made divorces easier (less costly) to obtain, we include also a dummy variable (labelled DIREFORM) which picks up the change in average legal incomes attendant on simplification of the divorce act. (We expect that DIVORCE will be positively related to legal incomes, but DIREFORM will be negatively related).

Estimating this model on Canada-wide data we obtain:

\begin{tabular}{|c|c|c|c|c|}
\hline AVINCLAW $=$ & $\begin{array}{c}-10.99 \\
(2.69) \\
((16.6)) \\
* *\end{array}$ & $\begin{array}{c}\text { + } 1.26 \text { SRATIO } \\
(.204) \\
((38.0)) \\
* *\end{array}$ & $\begin{array}{c}+1.07 \text { TRENDY } \\
(.291) \\
((13.58)) \\
* *\end{array}$ & $\begin{array}{c}.0091 \text { DEVY } \\
(.0073) \\
((1.56))\end{array}$ \\
\hline & $\begin{array}{r}.224 \\
(\end{array}$ & $\begin{array}{l}\text { HOUSE }+.021 \\
.097) \\
5.25))\end{array}$ & $\begin{array}{l}\text { DIVORCE }-.042 \\
(.081) \\
((.36))\end{array}$ & $\begin{array}{l}\text { IREFORM } \\
.0698) \\
((.36))\end{array}$ \\
\hline
\end{tabular}

Standard error in parentheses ( )

F statistic in double parentheses (( ))

$\mathrm{R}^{2}=.918$

** statistically significant at $1 \%$

AVINCLAW - natural logarithm of average real total income for lawyers in independent professional practice.

SRATIO - natural logarithm of population to lawyer ratio

TRENDY - natural logarithm of trend real per capita disposable income 1956-80

DEVY - percentage deviation of actual per capita real disposable income from trend

The service ratio, trend increases in per capita income and housing starts are all statistically significant, and with the expected signs. The estimated coefficient on SRATIO implies that a $5 \%$ increase in the number of lawyers will, ceteris paribus, reduce legal incomes by about $6 \%$. However, cyclical deviations of per capita income from trend and the divorce variables are not statistically significant.

Since Canada-wide data aggregates information on a wide range of regional markets for legal services, we prefer estimates derived from provincial level data. In this paper we report estimates derived from the four 
Atlantic provinces (Newfoundland, Nova Scotia, Prince Edward Island and New Brunswick) for the period 1956 to 1980 . (Using the Atlantic Provinces enables us to examine more closely the influence of future supply flows see Section 3). In ponling data from different provinces over time we adopt the suggestion of Kmenta (1971: 508-512) to deal with the possibility of heteroskedasticity. Since salaried legal aid lawyers may reduce the amount of legal business going to independent legal practitioners, we include in the regressions which deal with the Atlantic provinces a variable LEGALAID to measure the impact that the introduction of salaried legal aid plans may have had on average professional incomes in provinces which had such plans, for the years they have been in existence.

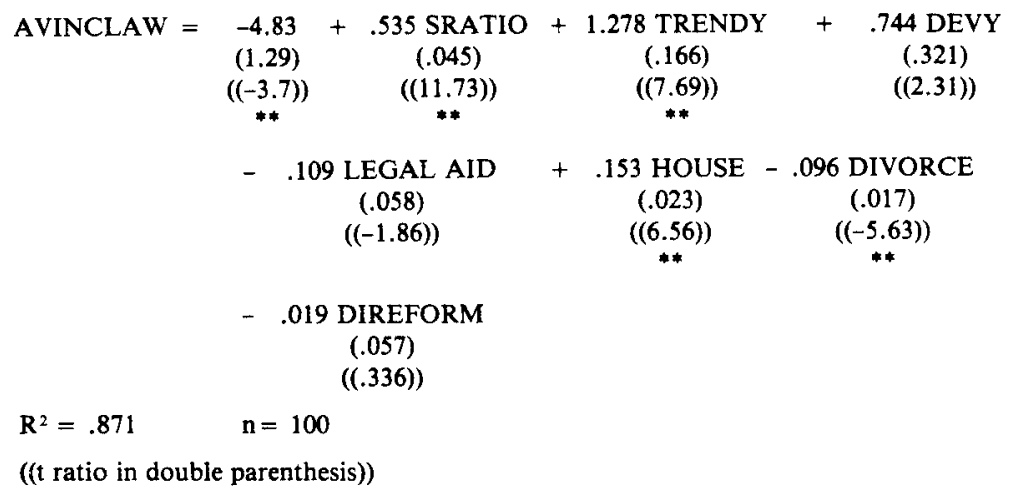

The estimate we obtain of the relationship between the service ratio and average professional incomes for lawyers in the Atlantic Provinces fluctuates over a fairly narrow range (.54 to .59) in a variety of specifications in other words, this estimate is rather robust to the specification of the aggregate relationships.

5 Self-employed professionals have the option of naming their financial year-end, and during periods of inflation when income tax is indexed (i.e., post 1973) they may well choose a date other than December 31 st. Income which is received after that date would then be part of the next financial year's income and tax year. One therefore benefits from both lower tax rates (an additional year of indexing) and from deferring tax if one names a date such as January 31 as one's financial year end. What appears as, for example, 1976 incomes in D.N.R. statistics may in fact stem almost entirely from economic activity in 1975 . We therefore experimented with a specification where average incomes in year $t+1$ were regressed on explanatory variables for year $t$. Poorer fits were obtained and this specification was, in consequence, dropped. 
Equation 2:2 indicates that a $1 \%$ increase in housing starts is associated with a $0.153 \%$ increase in average incomes. The existence of salaried legal aid does not have a statistically significant impact on incomes of lawyers perhaps because the legal aid clientele was not previously able to hire lawyers. An unexpected finding is the negative relationship between divorce frequency and legal income - but this variable is highly correlated with TRENDY and, as a result, this coefficient estimate may be unreliable, due to multi-collinearity ${ }^{6}$.

Overall, equation 2:2 indicates lawyers should have grounds for optimism regarding their future income prospects since the coefficient on TRENDY is 1.27 , indicating that a $1 \%$ increase in average disposable income will produce a $1.27 \%$ increase in legal incomes. This would be consistent with a view of legal services as a luxury good, whose consumption rises more than in proportion to increases in consumer income. However, the income elasticity of legal earnings are quite sensitive to the specification used and in some specifications are less than $\mathbf{1 . 0}$ or not significantly different from 1.0. Hence, we prefer a more cautious interpretation - that legal services may be a luxury good, implying that rising personal incomes in the population at large may counter-balance a trend to decreasing incomes as the population to lawyer ratio falls but it is more likely that legal incomes (if the service ratio were constant) would simply rise at the same rate as the incomes of the population at large.

\section{OVER-SUPPLY IN THE FUTURE?}

Between 1971 and 1980, the average real earnings of self-employed lawyers in Atlantic Canada fell by $11.7 \%$, somewhat less than the $15.6 \%$ decline in the average real earnings of all self-employed Canadian lawyers. In Atlantic Canada, average 1980 earnings were $\$ 38922$, substantially below the Canadian average of $\$ 49481$ (DNR, Taxation Statistics). Bet-

6 Similarly, a strong reason for caution in presuming that legal services are a luxury good, as implied in equations $2: 1$ or 2:2, is the high degree of collinearity between the variable DIVORCE and the variable TRENDY. These variables have a simple correlation of 0.9 in Newfoundland and New Brunswick data, 0.95 in P.E.I. data and 0.97 in Nova Scotia data. This multi-collinearity can be expected to produce highly imprecise estimates of the coefficients of the variables DIVORCE and TRENDY (see Kmenta: 1971, 380-391). (The variable SRATIO correlates -.67 with TRENDY in Atlantic Canada as a whole).

If one omits the DIVORCE variable from equation $2: 2$, the co-efficients on other variables change only marginally, except for that on TRENDY, which falls to 0.917 . (Standard error $=.099$ ). Hence, if we omit the DIVORCE variable we would conclude that average legal incomes may rise less than proportionately to trend income (although we cannot reject the hypothesis of unitary income elasticity). See OSBERG, 1983, pp. 34-40. 
ween 1961 and 1964, the average number of law graduates from the region's two law schools was 40 ; the $1977-1980$ average was 221 , (2/3 from Dalhousie, the remainder from UNB) with the major portion of the increase in graduates coming in the period 1969 to 1974 . Since the total population of the Atlantic region grew by only $17.5 \%$ between 1961 and 1980 and is forecast by Foot $(1982)$ to rise by only another $18 \%{ }^{7}$ by the year 2000 , the service ratio (population per lawyer) has clearly fallen, and will continue to fall, dramatically.

However, the interpretation of the 'service ratio' as an indicator of effective supply in future years is made more difficult by a simultaneous trend to a much greater percentage of female lawyers ${ }^{8}$ among new graduates. If female lawyers follow traditional female patterns they will work fewer hours per year and spend more years out of the labour force. On the other hand, if they had followed traditional patterns, they would not now be lawyers, so one must be cautious in predicting the extent to which the service ratio will over-estimate effective supply on this account. Indeed, if there is a trend to later retirement (perhaps partly due to greater financial pressures on self-employed lawyers, who lack prepaid pension plans) and/or if the spread of word-processing and other computer technology increases the productivity of lawyers, then projections of the service ratio which use historic attrition data will under-estimate effective supply. Exogenous institutional changes (such as a new constitution or no-fault automobile insurance) will also alter demand conditions.

Forecasting average future legal earnings is therefore a complex task, and one that becomes especially complex when one considers the importance of the decisions to practice law and/or to migrate to another jurisdiction. Surveys of Dalhousie's graduating classes of 1975 to 1979 undertaken two years after graduation indicate that an average $60 \%$ of Dal law graduates enter private practice and an average $60 \%$ of those admitted to the bar are admitted in the Atlantic provinces. Both fractions are fairly constant from 1975 to 1979 and together imply that only some $36 \%$ of Dalhousie graduates enter private practice in the Atlantic provinces. We have argued above that during the 1960's and 1970's the queue of potential entrants to law schools and the discrete decisions (of university funding agencies) with respect to law school expansion meant that the supply side of this labour market could be seen as varying exogenously. This implies that single equation estimation can identify demand relationships. However since the late 1970's, the decision as to whether to practice law at all (either in private practice or as an in-house lawyer) has emerged as an important

7 Simple average of 14 alternative projections of FOOT, (1982:94).

8 At Dalhousie, the increase is from roughly $5 \%$ to over $35 \%$ of the student body. 
issue for new law graduates. If this trend continues, then the number of law school seats will no longer uniquely determine aggregate supply. Econometric models of the Canadian legal market will then have to be simultaneous equation models, since economic theory would predict that average earnings as a lawyer (which even for in-house lawyers are set with reference to potential earnings in private practice) will crucially affect this decision.

At present, the data does not exist for such a simultaneous equations model (since historic data refers to supply rationed periods) but one can postulate probable upper and lower bounds for future supply responses. Two scenarios for future trends probably constitute upper and lower bounds to future trends in the flow of new graduates into the private practice of law: (a) a continuation of present trends (i.e., same class size, $40 \%$ outmigration, $30 \%$ of new graduates decide not to practice and $2.7 \%$ retire each year) and (b) a gradual decline in the fraction entering private practice to $30 \%$ by the year 2000 , and continuation of other trends (which implies that in the year 2000 only $18 \%$ of new graduates enter private practice in Atlantic Canada).

If (a) is true, one can project that the legal service ratio in Atlantic Canada will fall by the year 2000 to $54 \%$ of its 1980 level. If there is a trend away from private practice, it may only fall to $67 \%$ of its 1980 level $^{9}$. A drop of $46 \%$ in the service ratio will, if estimates of equation 2:2 are correct and if the market for legal services has the same structure over the next fifteen years as in the past fifteen-five, produce a fall of $25 \%(=.54 \times 46 \%)$ in average legal incomes. If there is a trend away from private practice such that, by 2001 , only $30 \%$ of Dalhousie graduates enter private practice (6/10 in the Atlantic provinces, hence $18 \%$ of graduates enter private practice in the Atlantic provinces), then the service ratio will fall only to $67 \%$. This fall of $33 \%$ can be expected, if $2: 2$ is correct and if market structure remains unchanged, to produce a fall of $18 \%(=.54 \times 33 \%)$ in average legal incomes.

However, if we use the relationship between the service ratio and legal incomes of equation 2:1, the fall in incomes will be more dramatic. Assuming no change in the proportions entering private practice, the service ratio decline is $46 \%$ and the decline in average incomes is $58 \%(=46 \% \times 1.26)$. Assuming declines in entry to private practice, the service ratio decline is $33 \%$ and the decline in average incomes is $42 \%(=33 \% \times 1.26)$.

If legal services are a luxury good, a renewal of economic growth might produce some counterbalancing optimism for legal incomes. However, even the most optimistic possible coefficient of 1.27 on TRENDY (from equa-

9 For details of the calculations see OSBERG, 1983. 
tion $2: 2$ ) would imply that the increase in average real wages of $5.9 \%$ forecast by 1990 by the Economic Council of Canada (1984: 3) will produce only a $7.4 \%$ increase in legal incomes. And we have argued that the true coefficient on TRENDY is likely to be much closer to the 1.07 of equation 2:1 and may not be much different from 1 . Hence it is quite likely that legal incomes will decline both absolutely and relatively in future years.

\section{SOCIAL POLICY}

Currently, law schools can be quite selective in their admissions policies since there are several applicants for each available place. As a result, it is highly likely that the current student population could earn a better-thanaverage salary even if they had not gone on to law school. Separating the influences on earnings of natural «ability ${ }^{10}$ from (1) the influences of education in providing training in useful skills and (2) the restraints on competition created by professional associations is a highly complex task. It is, however, fairly likely that the decline in the relative earnings of lawyers will imply that some of the students who have the best alternative opportunities for earnings will choose those alternatives. Certainly many people will always be attracted to the legal profession by its non-monetary rewards, but some people are certain to be discouraged by declining income - implying that law schools will not be able to be as selective in future years as they would otherwise have been. Even if the number of law school students does not decrease, the composition of that student body is likely to change ${ }^{11}$. By traditional standards of 'quality', the average 'quality' of entering classes is likely to decline.

Whether changes in the composition of the student body of the professional faculties and / or declines in its average 'quality' is a 'bad thing' or not depends partially on whether the traditional selection criteria for entering students actually predict accurately professional excellence later in life. However, even if 'quality' does decline it is not immediately obvious that this is necessarily 'bad' from a social point of iew. Suppose that there have been monopoly rents in the practice of law, due to the restrictions on competition created by the various law societies. Suppose further that these monopoly rents are distributed among the whole profession, but access to the profession depends upon one's 'ability'. People will then favour law

10 For a discussion of the difficulties involved in measuring ability see OSBERG, 1981, pp. 80-90.

11 If males continue to be paid more in the general labour market than females with similar education one is, for example, likely to see more well-qualified potential male students choose other alternatives - hastening the 'feminization' of the profession. 
over other potential careers up to the point where the return to their 'abilities' plus their share of the legal profession's monopoly rents in equal to the return to their 'abilities' in the practice of another profession. In this situation there will be a higher average level of 'ability' among the legal profession than in competing professions since 'ability' used in law practice will receive a return composed of two elements - the 'marginal product' of ability and a share in the professions monopoly rents. Whether the 'marginal product' of ability in law exceeds or falls short of its marginal product elsewhere will depend on the extent of constraints in all potential uses.

From the point of view of society as a whole, intelligent people are a scarce resource. It is an open question whether society as a whole is better off if they are attracted by high earnings to the profession of law or if they are spread more evenly in scientific research, business, or government. The professional associations are, as interest groups, quite legitimately concerned with the average earnings of their membership and the average 'quality' of new professionals. On both grounds there will undoubtedly be pressure on the universities to restrict enrolment. Whether universities should respond to these pressures is entirely another issue.

In addition to the issue of the social benefits of the average quality of legal services there is the issue of the social benefits of the quantity of legal services. A very crude attempt to sort out this issue would take as a measure of the social benefit of a service the price which individuals are willing to pay for the service. By this conception, one should expand the numbers of lawyers until their incomes decline to the point at which the income differential which they receive for practicing their profession is just sufficient to repay the full costs of the investment in their training, plus interest. In essence, this is the 'equilibrium' supply of lawyers estimated by Pashigian (1977) for the U.S. and espoused by Stager (1983) for Canada. Despite the fact that the service ratio for lawyers declines fairly dramatically over the next twenty years, even the lower incomes predicted above would repay the costs of university training, if the alternative is to earn an average salary. If incomes earned are an adequate reflection of benefits provided to society, enrolment limitations which maintain the market in 'under-supply' also imply that there is a sub-optimal level of supply of legal services.

If we adopt the market criterion of 'ability and willingness to pay', we cannot, therefore, conclude that enrolment limitations are appropriate at this time. However, many economists have questioned whether this market criterion is an appropriate indicator of social benefits in the context of a professional service, where the essence of the buyer/seller relationship is an inequality of knowledge between the seller and the buyer of the service. The 
optimality of the market criterion depends on: (1) the assumption that the distribution of wealth is 'just'; (2) the presumption that no 'externalities' exist in the consumption of the commodity in question; (3) the idea that the consumer is the individual who is best able to judge whether his well-being is increased by the purchase of a particular commodity and (4) on the convergence of actual prices and quantities in the market place to those that would be generated by perfectly competitive markets - i.e., a Paretooptimal general equilibrium. Even leaving (1) aside, these criteria are unlikely to be satisfied in the market for legal services.

When there are transactions costs, an economy may be in 'equilibrium', but one cannot in general show that such an equilibrium has desirable welfare properties ${ }^{12}$. However, legal costs are transactions costs, par excellence. The classic statements of economies in general equilibrium (e.g., Debreu 1962) refer to a theoretical world where there is no theft and where market participants trade unambiguously defined property rights but if all property and other rights were unambiguously defined, there would be no need for lawyers. The legal profession exists because rights are ambiguous, because there is theft and because conflicts arise over the meaning of contracts. In short, the use of private returns as an unambiguous indicator of social benefits may be justifiable in some worlds, but they are not worlds which include lawyers.

Moreover, the consumer of legal services approaches the seller of legal services in substantial ignorances as to what sort of service is required and relies on the professional practitioner to decide what services are required. There is the possibility, therefore, of 'supplier-induced demand'.

In addition, the practice of law inevitably generates externalities. To put it somewhat starkly, if avaricious lawyer $\mathrm{A}$ induces bumbling client $\mathrm{B}$ to sue conniving $C$, then $C$ must engage defence councel $D$. $A$ and $D$ are both certain to make money but only one of $B$ or $C$ will. Although legal disputes may be expensive, they do not add to the total of society's wealth, rather they concern quarrels over its division. Initiating litigation imposes costs on the defendant and, if the case goes to trial, on society at large through the costs of the court system - but only a fraction of these costs are borne by the litigant. In addition, a successful suit creates incentives for potential defendants to avoid similar future legal action, either by mitigating risks or by drafting legal protections against liabilities. Expanding the supply of

12 The point is most easily seen when transactions costs are very great - so great that no trade occurs. A sort of 'equilibrium' exists, but Pareto superior re-allocations are clearly possible. Lower transactions costs prevent only 'some' trade, but market equilibrium still loses its Pareto optimal status and observed market prices no longer represent 'social' costs - for an early discussion see HAHN (1971). 
lawyers may, therefore, be seen as leading to an overly litigious society, mired in expensive disputes and the complex documentation required to forestall potential disputes. Alternatively, since justice done to one person is a contribution to a more just society, expanding the supply of lawyers may be seen as leading us towards a more just society, which is presumably a value we all share.

At the present time the evaluation of the social benefits involved in 'maintaining standards' in the legal profession or in expanding the number of lawyers must remain matters of judgement. The private benefits to professional practice, in the form of the personal incomes of practitioners, are only part of the picture. They are, however, an important part and the aim of this paper has been to bring some new information to the debate on legal numbers by providing more exact data on future private benefits - i.e., on the impact of future service ratios on average professional incomes in Canada and in the Atlantic provinces. The debate on the social benefits of the expanding supply of lawyers is a much larger debate and will doubtless continue for many years.

\section{BIBLIOGRAPHY}

ALTMAN AND WEIL INC., Economic Survey of Canadian Law Firms, Ardmore, Pennsylvania, 1982.

DEBREU, Gérard, Theory of Value, an Axiomatic Analysis of Economic Equilibrium, New York, John Wiley and Sons, 1962.

Economic Council of Canada, Steering the Course, 21st Annual Review, Ottawa, 1984.

FOOT, David K., Canada's Population Outlook: Demographic Futures and Economic Challenges, Toronto, Canadian Institute for Economic Policy, 1982.

FREEMAN, R.B., "Legal 'Cobwebs': A Recursive Model of the Market of New Lawyers", The Review of Economics and Statistics, Vol. 58, No 2, May 1975, pp. 171-180.

HAHN, F.H., «Equilibrium with Transaction Costs», Econometrica, Vol. 39, No. 3, May 1971, pp. 417-439.

KMENTA, Jan, Elements of Econometrics, New York, MacMillan Publishing Co. Inc., 1971.

MANSFIELD, Edwin, Micro-Economics, Theory and Applications, Fourth Edition, New York, W.W. Norton \& Co., 1982. 
MELTZ, N.M. \& D. STAGER, The Structure of Earnings by Occupation in Canada 1931-1974, Anti-Inflation Board Discussion Paper, Ottawa, 1977.

OSBERG, L., Economic Inequality in Canada, Butterworth's, Toronto, 1981.

___ _ Demand and Supply for Lawyers, Dentists and Physicians in the Atlantic Provinces, Dalhousie University, mimeo, July 1983.

PASHIGIAN, B.P., «The Market for Lawyers: The Determinants of the Demand for and Supply of Lawyers", Journal of Law and Economics, Vol. 20, April 1977, pp. 53-85.

REVENUE CANADA TAXATION (1958-1982), Taxation Statistics: Analyzing the Returns of Individuals for the 1956 to 1980 Taxation Year and Miscellaneous Statistics, Ottawa, Ontario.

STAGER, D., «Are There too Many Lawyers?» Canadian Public Policy, Vol. IX, 2 1983, pp. 245-249.

STATISTICS CANADA (1956-1980), Vital Statistics: Volume II, Mariages and Divorces, Ottawa, Ontario, 1957-1981.

STATISTICS CANADA (1975-1980), The Consumer Price Index, Ottawa, Ontario. STATISTICS CANADA (1965-1980), Provincial Economic Accounts, Experimental Data, Ottawa, Ontario.

STATISTICS CANADA (1978-1982), Estimates of Population by Sex and Age for Canada and the Provinces, Ottawa, Ontario.

STATISTICS CANADA, Estimates of Population for Canada and the Provinces, Ottawa, Ontario, Various Years.

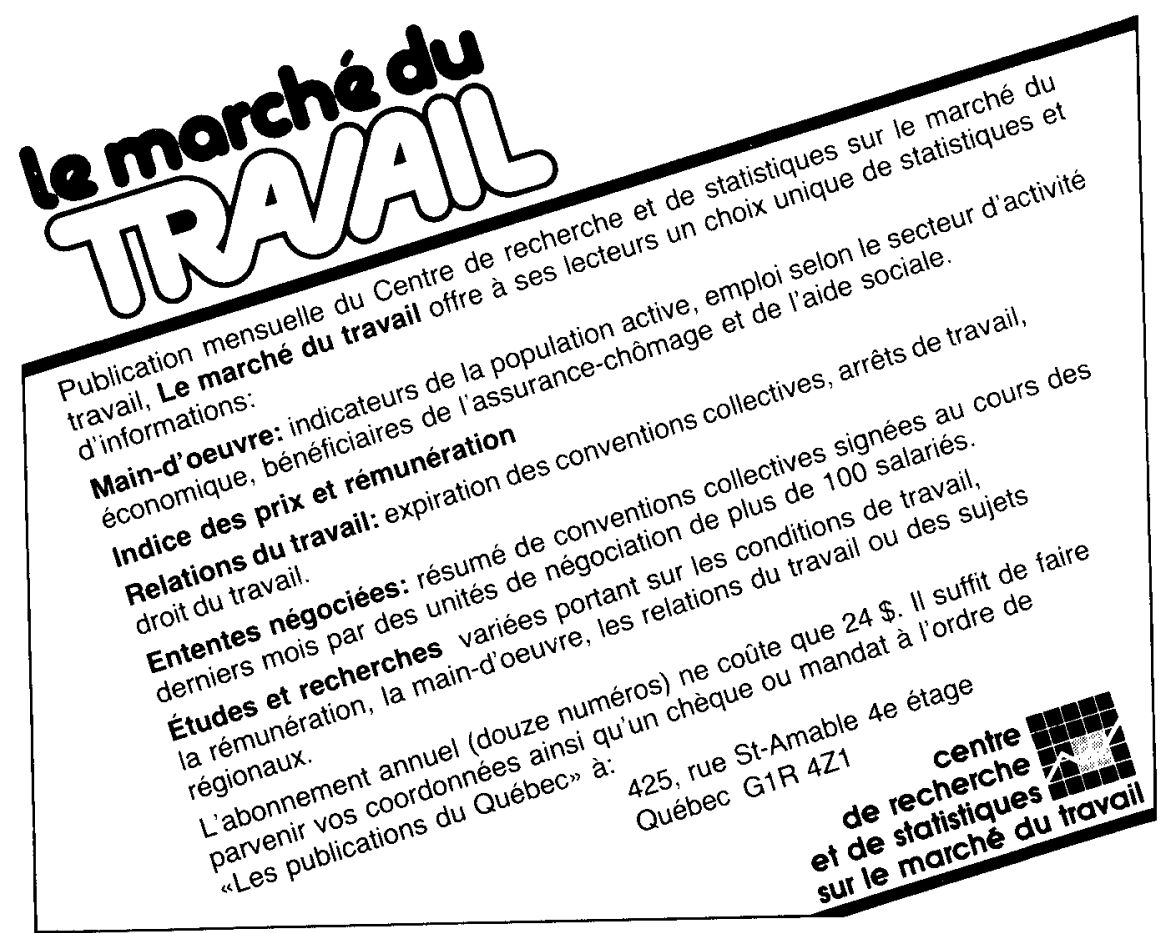

